\title{
Influence of culture conditions on extracellular polymeric substances production by the white rot fungi Phanerochaete chrysosporium
}

\author{
Ningjie $\mathrm{Li}^{1,2, a}$, Linbo $\mathrm{Fu}^{1,2}$, Lei $\mathrm{Wu}^{1,2}$, Zhongwei Chen ${ }^{1,2}$ and Qi Lan ${ }^{1,2}$ \\ ${ }^{1}$ College of Environmental Science and Engineering, Guilin University of Technology, Guilin 541004, China \\ ${ }^{2}$ Guangxi Key Laboratory of Environmental Pollution Control Theory and Technology, Guilin University of Technology, Guilin 541004, \\ China
}

\begin{abstract}
The extracellular polymeric substances of white rot fungi play an important role in the adsorption of heavy metals, but the influence of culture conditions on extracellular polymeric substances production is still unknown. In this paper, we researched on the influence of temperature, incubation time, the rotational speed and the inoculation volume on the yield of extracellular polymeric substances produced by Phanerochaete chrysosporium, a model strain of white rot fungi. The results show that the optimum culture conditions for Phanerochaete chrysosporium to produce extracellular polymeric substances was culturing at $40{ }^{\circ} \mathrm{C}$, incubating for $5 \mathrm{~d}$, rotating at $100 \mathrm{rpm}$, and inoculating $0.5 \mathrm{ml}$ of spore suspension with concentration of $2.5 \times 10^{6}$ spores $/ \mathrm{ml}$. The highest yield of EPS was $234.65 \mathrm{mg} / \mathrm{g}$ when the fungi was cultured at $100 \mathrm{rpm}, 40{ }^{\circ} \mathrm{C}$ and incubated for 5 days. This study can provide useful information for the follow-up experiments related to extracellular polymeric substances of white rot fungi.
\end{abstract}

\section{Introduction}

Extracellular polymeric substances (EPS) are a number of polymer secreted by microorganisms under certain environmental conditions. The main sources of these macromolecular substances are as follows: cell secretion, cell surface material shedding and cell hydrolysis, etc [1]. The composition of EPS are polysaccharides, proteins, humus and lipids, etc, in which polysaccharides and proteins usually are main component. The structure of EPS are mucus layer, loosely bound EPS (LB-EPS) and tightly bound EPS (TB-EPS). EPS has been widely studied at home and abroad because of its strongly heavy metal adsorption capacity. For instance, Yun $\mathrm{Cu}$ [2] had studied the process of activated sludge culture, the change of the carbon nitrogen ratio had an effect on EPS composition of activated sludge and on different metal adsorption by EPS. The results showed that the adsorption of $\mathrm{Cd}$ ( II ) by EPS varied from $120 \mathrm{mg} / \mathrm{g}$ to $170 \mathrm{mg} / \mathrm{g}$, and the adsorption of $\mathrm{Cu}$ (II) by EPS varied from $40 \mathrm{mg} / \mathrm{g}$ to $160 \mathrm{mg} / \mathrm{g}$ [2].

The researches of EPS are mainly in the aspect of bacteria and the researches on fungal EPS are less. Previous reports have shown that EPS of edible fungi have various biological activities, which has been widely studied and applied in medicine and food industry, such as drug synthesis [3,4], food additives [5], etc. Besides, the EPS of fungus has important application value in environmental pollution treatment, especially in the treatment of heavy metal wastewater [6] and heavy metal contaminated solid waste composting [7]. The degradation of lignin by white rot fungus Phanerochaete chrysosporium was first reported in Science in the early 1980s, and has been studied for more than 30 years until now. White rot fungi can not only degrade refractory organic matter, but also deal with complex heavy metal pollution in water and soil. The study of Wang et al [8] has shown that EPS of white rot fungi played an important role in the adsorption of heavy metals Cd( II ). It is clear that the research prospect of saprophytic fungi EPS is excellent.

The production of extracellular polymer of microorganisms may be affected by culture conditions [8]. But the effective information of EPS of white rot fungi in this area is little. Therefore, it is necessary to study the production characteristics of EPS of white rot fungi under different culture conditions. In this study, the optimization of culture conditions for EPS production by white rot fungi was researched. It is expected to provide information for the further studies on EPS of white rot fungi.

\section{Materials and Methods}

\subsection{Source of microorganism}

In this experiment, the model strain of white rot fungi Phanerochaete chrysosporium BKM-F 1767 (CCTCC

*Corresponding author: ${ }^{a}$ echoningjie_333@126.com 
AF96007) was used, which was purchased from China Center for Type Culture Collection, Wuhan.

\subsection{Strain culture}

The white rot fungi was cultured in trace element solution. $20 \mathrm{mmol} / 1$ sodium tartrate buffer was used to as the solvent of the culture medium ( $\mathrm{pH} 4.5)$. Per liter of medium contained $2 \mathrm{~g} \mathrm{KH}_{2} \mathrm{PO}_{4}, 0.1 \mathrm{~g} \mathrm{CaCl}_{2}, 0.5 \mathrm{~g}$ $\mathrm{MgSO}_{4}, 0.115 \mathrm{~g} \mathrm{FeSO}_{4} \cdot 7 \mathrm{H}_{2} \mathrm{O}, 0.112 \mathrm{~g} \mathrm{MnSO}_{4} \cdot \mathrm{H}_{2} \mathrm{O}$, $0.089 \mathrm{~g} \mathrm{ZnSO}_{4} \cdot 7 \mathrm{H}_{2} \mathrm{O}, 0.05 \mathrm{~g} \mathrm{CuSO}_{4} \cdot 5 \mathrm{H}_{2} \mathrm{O}, 0.001 \mathrm{~g}$ Vitamin $\mathrm{B}_{1}, 0.12 \mathrm{~g} \mathrm{NH} \mathrm{NH}_{4} \mathrm{Cl}, 10 \mathrm{~g}$ glucose. Before inoculation, the medium was sterilized at $105{ }^{\circ} \mathrm{C}$ for 30 $\min$.

Experiments were performed in a thermostatic incubator. By setting different culture temperature, culture period, culture rotate speed, inoculum volume to examine the culture conditions on the EPS properties of white rot fungus. Inoculation was carried out using spore suspension. The spore concentration was controlled at about $2.5 \times 10^{6}$ spores $/ \mathrm{ml}$ by measuring the absorbance of the spore suspension at $400 \mathrm{~nm}$ [9].

\subsection{EPS extraction}

There are many kinds of EPS extraction methods. For example the physical methods include ultrasound, ultrasonic centrifugation, steam extraction, high-speed centrifugation, etc.. The chemical methods include $\mathrm{NaOH}$ extraction, ethanol extraction, EDTA extraction, phosphate buffer solution extraction, formaldehyde extraction and so on. In order to prevent cell injury and the impact of chemical substances on the subsequent analysis, in the experiment a gentle high-speed centrifugation method was used to extract EPS.

The filter paper was used for separation of cultured mycelia from medium, after which mycelia were washed 4 or 5 times with ultrapure water and then centrifuged at $5000 \mathrm{rpm}$ for $10 \mathrm{~min}$ to obtain fungal mycelia. $3 \mathrm{ml}$ of ultrapure water was added to per $\mathrm{g}$ of wet mycelia and the mixture was centrifuged at $10,000 \mathrm{rpm}$ for $20 \mathrm{~min}$ to obtain a supernatant. This solution was considered as EPS solution of white rot fungus.

\subsection{Analysis of the composition of EPS}

White rot fungal extracellular polymers are mainly composed of polysaccharides and proteins [1]. So the determination of the content of protein and polysaccharide can be considered as the content of EPS. The final data representation was divided by the sum of the contents of the dry cell weight. The polysaccharide was determined by anthrone sulfuric acid method, with glucose as a standard substance. Determination of protein used coomassie brilliant blue method, with bovine serum albumin as a standard material. Dry cell weight was determined by weighing the vacuum freezedried mycelia after extraction of EPS. 3 parallel groups were set in each experiment, and the final results of the amount of each component and the total amount of EPS was the average of three parallel experimental results.

\section{Results and Discussion}

\subsection{The effect of temperature on the yield of EPS}

From Figure. 1, we can see that the yield of polysaccharides and protein were increasing at the culture temperature range from $25{ }^{\circ} \mathrm{C}$ to $40{ }^{\circ} \mathrm{C}$, and the growth of polysaccharides content was stable. The growth rate of protein from $25{ }^{\circ} \mathrm{C}$ to $35^{\circ} \mathrm{C}$ was lower than that from $35{ }^{\circ} \mathrm{C}$ to $40{ }^{\circ} \mathrm{C}$. The lowest yield of polysaccharide and protein were $152.18 \mathrm{mg} / \mathrm{g}$ and 0.11 $\mathrm{mg} / \mathrm{g}$ respectively at $25{ }^{\circ} \mathrm{C}$, and the highest yield were $177.39 \mathrm{mg} / \mathrm{g}$ and $0.72 \mathrm{mg} / \mathrm{g}$ respectively at $40{ }^{\circ} \mathrm{C}$. The yield of EPS produced by Phanerochaete chrysosporium was the sum of the yield of polysaccharide and that of protein. By comparison, the yield of protein was quiet low, so that the yield curve of polysaccharide could be seen approximately as the EPS yield curve. In the temperature range from $25{ }^{\circ} \mathrm{C}$ to $40{ }^{\circ} \mathrm{C}$, the yield difference of polysaccharide in all experiment groups was $25.21 \mathrm{mg} / \mathrm{g}$ and that of protein yield was $0.61 \mathrm{mg} / \mathrm{g}$. From the results, it can be concluded that in the temperature range set in this experiment, the fungi Phanerochaete chrysosporium displayed a normal growth, and higher temperature may be more conducive for fungal growth, with the highest yield of EPS 178.11 $\mathrm{mg} / \mathrm{g}$ at $40{ }^{\circ} \mathrm{C}$. The phenomenon was coincident with the optimal culture temperature used in other researches [10].

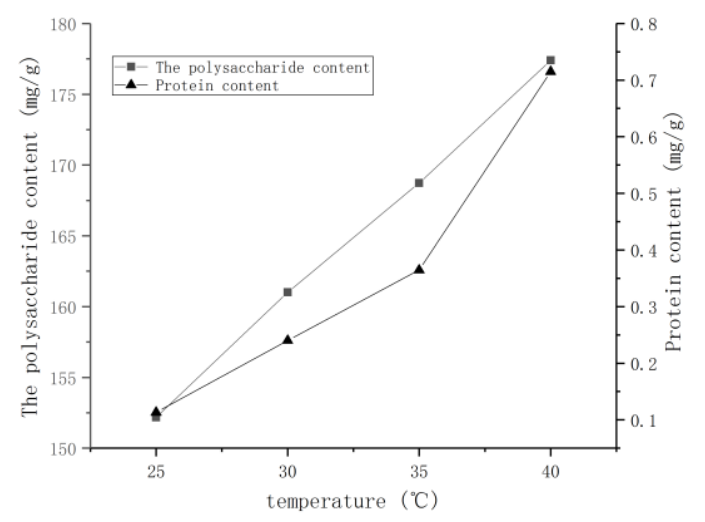

Figure 1. Effect of temperature on EPS production (incubating for $7 \mathrm{~d}$, rotating at $180 \mathrm{rpm}$, inoculating $2 \mathrm{ml}$ )

\subsection{The effect of culture period on the yield of EPS}

As shown in Figure 2, the yield of polysaccharides increased rapidly from $3 \mathrm{~d}$ to $5 \mathrm{~d}$, and the yield decreased after $5 \mathrm{~d}$, and the decline rate from $5 \mathrm{~d}$ to $7 \mathrm{~d}$ was higher than that from $7 \mathrm{~d}$ to $12 \mathrm{~d}$. The lowest yield of polysaccharide was $87.89 \mathrm{mg} / \mathrm{g}$ at $3 \mathrm{~d}$. The highest was $198.87 \mathrm{mg} / \mathrm{g}$ at $5 \mathrm{~d}$, which was 2.26 times as high as the minimum yield. The curve of protein yield was similar to that of polysaccharide yield. The lowest protein yield was $0.60 \mathrm{mg} / \mathrm{g}$, and the highest was $1.16 \mathrm{mg} / \mathrm{g}$, which 
was 1.93 times as high as the lowest yield. EPS production increased rapidly in the previous $5 \mathrm{~d}$ culture period when the fungus was at its rapid multiplication stage with enough nutrition in the medium [11]. At $5 \mathrm{~d}$, the highest yield of EPS in the stable period was 200.03 $\mathrm{mg} / \mathrm{g}$, and the yield of EPS decreased after $5 \mathrm{~d}$ in the decline period. So the best time for the extraction of EPS was at $5 \mathrm{~d}$. The decrease of nutrients in the medium would slow down the rate of EPS production. EPS can supplied as the carbon source and nitrogen source for the metabolic needs of the fungus in the late growth period [12].

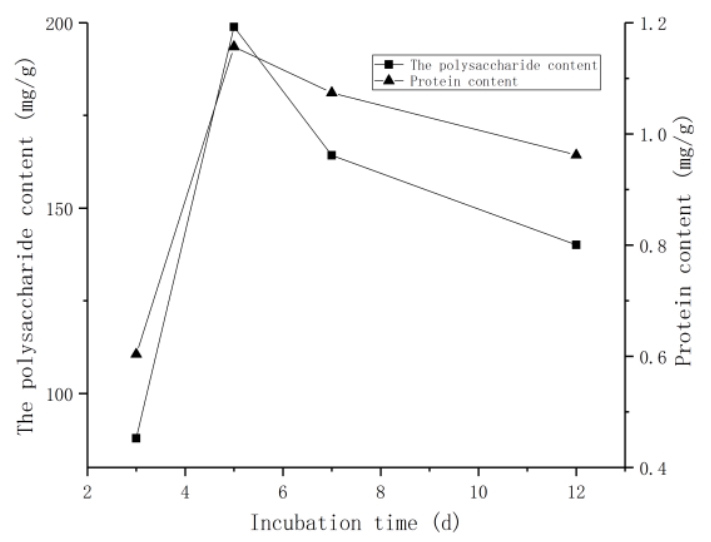

Figure 2. Effect of culture period on EPS production (culturing at $40{ }^{\circ} \mathrm{C}$,rotating at $180 \mathrm{rpm}$, inoculating $2 \mathrm{ml}$ )

\subsection{Influence of rotational speed on EPS production}

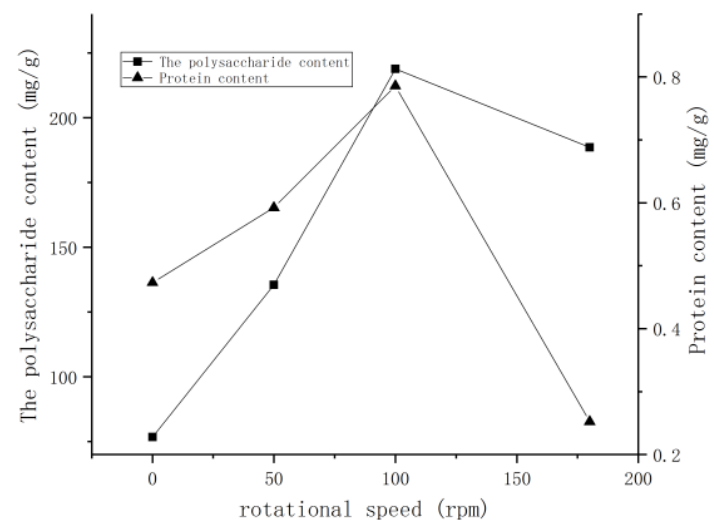

Figure 3. Effect of rotational speed on EPS production (culturing at $40{ }^{\circ} \mathrm{C}$, incubating for $5 \mathrm{~d}$, inoculating $2 \mathrm{ml}$ )

As shown in Figure 3, the yield of polysaccharide and protein showed an upward trend when the experiment was operated at rotational speed lower than $100 \mathrm{rpm}$, and the yield decreased at higher rotational speed $180 \mathrm{rpm}$. The lowest yield of polysaccharide was $76.76 \mathrm{mg} / \mathrm{g}$ under $0 \mathrm{rpm}$, while the highest was $218.87 \mathrm{mg} / \mathrm{g}$ under $100 \mathrm{rpm}$. The lowest yield of protein was $0.25 \mathrm{mg} / \mathrm{g}$ under 180rpm, and the highest was $0.79 \mathrm{mg} / \mathrm{g}$ under 100 $\mathrm{rpm}$. On the one hand, different rotational speeds would cause different dissolved oxygen amount and different nutrient transfer rate in the fungal culture medium [13]. The faster the rotational speed, the faster the nutrient transfer rate and the dissolution rate of oxygen. The increase of the two factors was beneficial for the fungal metabolism, as well as for the production of EPS. Even so, the concentration of dissolved oxygen and the transfer speed of oxygen and nutrition would not increase when the upper limit reached. In this study, the upper limit reached when the rotational speed was at 100 rpm, and the highest yield of EPS was $219.66 \mathrm{mg} / \mathrm{g}$. When the fungus was cultured at faster rotational speed under $180 \mathrm{rpm}$, the hydraulic shear force may be too large for the loosely bound EPS to stay on the surface of fungal mycelium. Part of EPS would be sheared off from fungal surface to the culture medium, resulting in the decrease of EPS production at $180 \mathrm{rpm}$. So the speed selection $100 \mathrm{rpm}$ was more suitable for EPS production by Phanerocheate chrysosporium.

\subsection{The effect of inoculation volume on the yield of EPS}

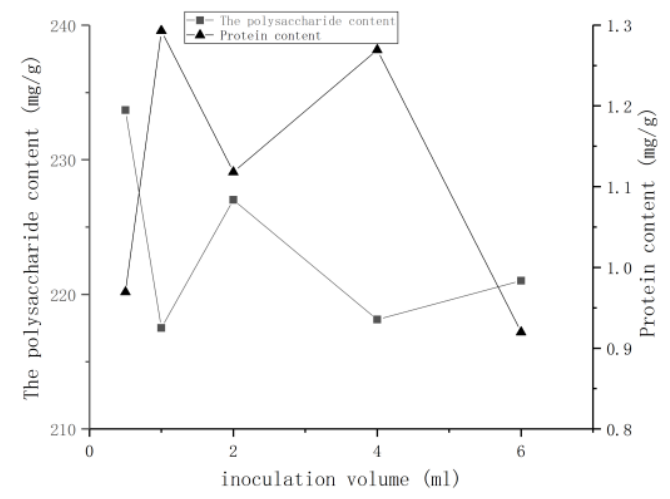

Figure 4.Effect of inoculation volume on EPS production (culturing at $40{ }^{\circ} \mathrm{C}$, incubating for $5 \mathrm{~d}$, rotating at $100 \mathrm{rpm}$ )

From Figure 4, we can see that with the change of inoculation volume, the yield of polysaccharides and protein was constantly changing. When the inoculation volume was $0.5 \mathrm{ml}$, the highest yield of polysaccharides was $233.68 \mathrm{mg} / \mathrm{g}$. When the inoculation volume was at $1 \mathrm{ml}$, the highest was $1.29 \mathrm{mg} / \mathrm{g}$. The highest yield of EPS is $234.65 \mathrm{mg} / \mathrm{g}$ with the inoculation volume of 0.5 $\mathrm{ml}$, but the amount of fungi biomass was much smaller than that in the other groups. More inoculation volume means more intense nutrition competition among fungal mycelium, so that the increase of inoculation volume more than $2 \mathrm{ml}$ did not lead to an outstanding increase of fungal biomass weight. In this experiment, the nutrition in the culture medium was suitable for the growth of $5.0 \times 106$ spores. From the above results, it was suggested that the inoculation amount $2 \mathrm{ml}$ would be probable with the culture medium in this study. 


\section{Conclusion}

From the above results, we can concluded that:

(1) The yield of EPS produced by Phanerocheate chrysosporium increased as the temperature increased from $25^{\circ} \mathrm{C}$ to $40{ }^{\circ} \mathrm{C}$.

(2) The yield of EPS was closely related to the growth period of the fungal strain. When the culture period was at $5 \mathrm{~d}$, the production of EPS was highest.

(3) When the rotational speed was probably at 100 rpm, the condition was most suitable for the yield of EPS by Phanerocheate chrysosporium.

(4) When the inoculation volume was $0.5 \mathrm{ml}$, the yield of EPS was the highest, reaching $234.65 \mathrm{mg} / \mathrm{g}$.

\section{Acknowledgements}

The study was jointly supported by the National Natural Science Foundation of China (51608142 and 51638006), and the Natural Science Foundation of Guangxi Province (2016GXNSFBA380076).

\section{References}

1. Jian L, Li BH, Guo XW, Gao B. Adsorption of heavy metal ions by extracellular polymer. Guangdong Chemical, 42:143-146 (2015).

2. Yuncu B, Sanin F D, Yetis U. An investigation of heavy metal biosorption in relation to $\mathrm{C} / \mathrm{N}$ ratio of activated sludge. Journal of Hazardous Materials. 137: 990-997 (2006).

3. Franz G. Polysaccharides in pharmacy:current applications and future concepts. Planta Medica. 55:493-497 (1989).

4. Gi-Young Kim, Gap-Seong Choi, Sang-Hee Lee, Yeong-Min Park. Acidic polysaccharide isolated from Phellinus linteus enhances through the upregulation of nitric oxide and tumor necrosis factoralpha from peritoneal macrophages. J. Ethnopharmacol. 95:69-76 (2004).

5. Yang B K, Ha J Y, Jeong S C, et al. Hypolipidemic effect of an exo biopolymer produced from submerged mycelial culture of Auricularia polytricha in rats. Biotechnol. Lett. 24:319-325 (2002).

6. Anna J W, Gadd G M. Oxalate production by woodrotting fungi growing in toxic metal-amended medium. Chemosphere. 52 (2003).

7. Huang DL, Zeng GM, Feng CL, Hu S, Jiang XY, Tang L, Su FF, Zhang Y, Zeng W, Liu HL. Degradation of lead-contaminated lignocellulosic waste by Phanerochaete chrysosporium and the reduction of lead toxicity. Environmental Science and Technology. 42 (2008).

8. Wang L, Chen GQ, Zeng GM, Zhang WJ, Fan JQ, Shen GL. Effects of Extracellular Polymers of White-rot Fungus on $\mathrm{Pb}^{2+}$ Adsorption on Microbial Cells. Environmental Science. 32:773-778 (2011).
9. Pellinen J, Abuhasan J, Joyce T W, Chang H M. Biological delignification of pulp by Phanerochaete chrysosporium. Journal of Biotechnology. 10:161170 (1989).

10. Pakshirajan, K. Jaiswal, S. Das, R. K. Biodecolourization of azo dyes using Phanerochaete chrysosporium: Effect of culture conditions and enzyme activities. Journal of Scientific \& Industrial Research. 70:987-991 (2011).

11. Li NJ, Zeng GM, Huang DL, Huang C, Lai C, Wei Z, Xu P, Zhang C, Cheng M, Yan M. Response of extracellular carboxylic and thiol ligands (oxalate, thiol compounds) to $\mathrm{Pb}^{2+}$ stress in Phanerochaete chrysosporium. Environmental Science and Pollution Research. 20:12655-12663 (2015).

12. Lei LM, Song LR, Ou DY, Han BP. Effects of nutrient conditions on exopolysaccharide production in water-bloom forming Cyanobacteria, microcystis aeruginosa. Acta Scientiarum Naturalium Universitatis Sunyatseni. 46: 84-87 (2007).

13. Zhao Y, Chen ZM. Influence of dissolved oxygen in the process of fermentation and its regulation. Food and Fermentation Sciences \& Technology. 52:1519 (2016). 